\title{
Ameliorative and Safety Characteristics of Argemone mexicana in Indomethacin-Induced Peptic Ulcer
}

\author{
Oluwafemi Ayodeji Idowu ${ }^{1 *}$ Rotimi Olusanya Arise ${ }^{2}$ \\ ${ }^{1}$ Department of Biochemistry, University of Ilorin, Ilorin, Kwara State, \\ Nigeria \\ 2 Department of Biochemistry, University of Ilorin, Ilorin Kwara State, \\ P.M.B 1515, llorin, Nigeria \\ Pharmaceut Fronts 2020;2:e133-e142. \\ Address for correspondence Oluwafemi Ayodeji Idowu, PhD, \\ Department of Biochemistry, College of Natural and Applied Sciences, \\ Oduduwa University, P.M.B 5533, Ile-Ife, Osun State, Nigeria \\ (e-mail: id4phemy@gmail.com; \\ idowu.oluwafemi@oduduwauniersity.edu.ng).
}

\begin{abstract}
Argemone mexicana (A. mexicana) is a plant traditionally used in Nigeria and some African countries to treat peptic ulcer disease. In this study, the ameliorative effect of ethanolic leaf extract of $A$. mexicana in indomethacin-induced peptic ulcer and its safety were investigated. Phytochemical screening was performed using standard procedures. Ulcer was induced in rats by single oral administration dose of $25 \mathrm{mg} / \mathrm{kg}$ body weight (b.w.) indomethacin followed by treatment with 100,200 , and $400 \mathrm{mg} / \mathrm{kg}$ b.w. ethanolic leaf extract of $A$. mexicana. Ulcerrelated indices such as gastric $\mathrm{pH}$, acidity, pepsin, and $\mathrm{Na}^{+} / \mathrm{K}^{+}$-ATPase activities, glycoprotein, and mucus contents were determined. The status of antioxidant enzymes (superoxide dismutase, catalase, glutathione peroxidase, reductase, and transferase) in the stomach and duodenum of the rats was also evaluated. Safety of the extract in the liver and kidney was investigated by chromosomal aberration. The results showed that alkaloids, flavonoids, phenolics, and saponins present in the extract as phytochemical constituents. The extract at

\section{Keywords}

- Argemone mexicana

- indomethacin

- peptic ulcer

- antioxidant

- chromosomal aberration $200 \mathrm{mg} / \mathrm{kg}$ b.w. significantly $(p<0.05)$ attenuated the gastric $\mathrm{pH}$, volume, and acidity of the stomach. It also significantly $(p<0.05)$ enhanced the glycoprotein and mucus contents in the mucosal membrane of rats. The status of antioxidant enzymes (superoxide dismutase, catalase, glutathione peroxidase, reductase, and transferase) in both tissues was also significantly improved. Study on safety evaluation revealed that the extract is relatively safe at the most active dose investigated. The study concluded that $A$. mexicana could serve as an alternative therapy for the development of a safer antiulcer drug.
\end{abstract}

\section{Introduction}

Peptic ulcer disease (PUD) is a disease of the stomach and/or duodenum. It is one of the gastrointestinal tract diseases affecting a large number of the populace globally in their everyday life. ${ }^{1}$ PUD manifests as an injury in the mucosal lining of the stomach or the duodenum. Ulcer that develops in the duodenum of the small intestine is called duodenal ulcer, while that which develops in the stomach is referred to as gastric or stomach ulcer. The former largely occurs in younger individuals and the latter in older age. The likelihood of developing PUD is approximately $10 \%$ for males and $4 \%$ for females. ${ }^{2,3}$ The disease usually results from an imbalance between gastric aggressive factors (acid, pepsin, reactive oxygen species) and defensive mucosal factors (prostaglandins, bicarbonate, mucin, antioxidant enzymes) induced by factors such as Helicobacter pylori infection, indiscriminate consumption of nonsteroidal anti-inflammatory drugs, smoking, diet, alcohol, and both physiological and physiological stress. ${ }^{4}$ The prevalence of PUD differs around the globe. While the prevalence has reduced in developed countries, the disease is still a burden in underdeveloped and developing countries like Africa. ${ }^{5}$ Poor hygiene capable of promoting the invasion of $\mathrm{H}$. pylori into the gastric lumen of the gastrointestinal tract, low socioeconomic status, poverty,
DOI https://doi.org/ 10.1055/s-0040-1722216. ISSN 2628-5088. (c) 2020. The Author(s).

This is an open access article published by Thieme under the terms of the Creative Commons Attribution License, permitting unrestricted use, distribution, and reproduction so long as the original work is properly cited. (https://creativecommons.org/licenses/by/4.0/)

Georg Thieme Verlag KG, Rüdigerstraße 14, 70469 Stuttgart, Germany 
lack of awareness about the disease as well as ineffective synthetic drugs in treating PUD among other reasons may have contributed to its burden. Antacids (e.g., aluminum and potassium hydroxides), histamine receptor blockers (e.g., famotidine and cimetidine), proton pump inhibitors (omeprazole, pantoprazole, and lansoprazole), prostaglandin analogues (misoprostol), and antibiotics (clarithromycin, metronidazole, amoxicillin) are among the class of synthetic drugs currently available for treating PUD; however, they are reported to produce adverse effects such as headache, male hormone disturbances, ${ }^{6}$ pneumonia, osteoporosis, vitamin $\mathrm{B}_{12}$ malabsorption, ${ }^{7}$ diarrhea, abdominal pain, nausea, vomiting, and constipation. ${ }^{8}$ This therefore necessitated the search for better modalities in treating PUD. Studies on medicinal value of plants which are of natural origin have shown that these plants not only afford gastroprotection but are also capable of accelerating ulcer healing, ${ }^{9}$ as various plants with different compositions are used either as decoction, concoction, or as food additives to combat PUD in folk medicine by many developing countries. In Nigeria, a West African country with a population of above 180 million, Argemone mexicana is one plant traditionally used to treat PUD in this region. Argemone mexicana is part of the plant family Papaveraceae, generally called prickly poppy in English, Mexican poppy in Mexico, Ghamoya in India, and locally called "Mafowokan-mo-mi"10 or "Egun-Arugbo,"11 "Akede,"12 and "Kwarko"13 in Southern, Eastern, and Northern parts of Nigeria, respectively. Therefore the antiulcer activity of ethanolic leaf extract of $A$. mexicana used as a folk medicinal herb in Nigeria to treat PUD was studied for the purpose of developing an effective and safer antiulcer drug.

\section{Materials and Methods}

\section{Collection of Plant Materials and Authentication}

Fresh leaves of A. mexicana were plucked in June 2015 from a tree in Shaki town, Oyo State, South-West, Nigeria. Leaves were identified and authenticated at the Department of Botany, University of Ilorin, Ilorin, Kwara State, Nigeria. A voucher number UIH0011171 was deposited in the herbarium.

\section{Chemicals}

5-Methoxy-2-([(4-methoxy-3,5-dimethyl-2-pyridinyl)methyl] sulfinyl)-1H-benzimidazole (omeprazole) and 1-(4-chlorobenzoyl)-5-methoxy-2-methyl-1H-indole-3-acetic acid (indomethacin) were purchased from Pauco Pharmaceutical (Anambra, Nigeria). Glutathione (GSH) peroxidase (GSH-px), GSH reductase (GSH-Red), GSH-S-transferase (GST), and superoxide dismutase (SOD) assay kits were procured from Randox Laboratories (Antrim, United Kingdom). All other chemicals commercially purchased were of standard grade.

\section{Extraction of Plant Materials and Preparation of Test Dose}

The fresh leaves were rinsed with distilled water, air-dried for 14 days at a temperature of $24 \pm 2^{\circ} \mathrm{C}$, and were made to a powder form with a mechanical blender (Mazeda Mill, MT 4100 , Japan). An amount of $500 \mathrm{~g}$ of the powder was macer- ated with absolute (99\%) ethanol (1.2 L) for 72 hours using a cold extraction method. The extract obtained was filtered with Whatman No. 1 filter paper and concentrated in a rotary evaporator (RE-300B model, product of Henan Touch Science, China). The test doses of 100,200 , and $400 \mathrm{mg} / \mathrm{kg}$ body weight (b.w.) were adopted in this study, according to the oral acute toxicity test performed by Das et $\mathrm{al}^{14}$ on ethanolic extract of A. mexicana which was in accordance with Organisation for Economic Co-operation and Development guidelines. ${ }^{15}$ The extract at these doses was dissolved in distilled water and administered to the experimental rats.

\section{Phytochemical Screening}

Standard methods were adopted to screen the ethanolic leaf extract of A. mexicana for secondary metabolites. ${ }^{16-18}$

\section{Experimental Animals}

A total of 36 Wistar rats of both sexes (male and female) aged approximately 4 months weighing $162 \pm 1.45 \mathrm{~g}$ were procured from the Animal Holding Unit, Biochemistry Department University of Ilorin, Ilorin, Kwara State, Nigeria. They were housed in a cage under standard conditions (temperature: $22 \pm 3^{\circ} \mathrm{C}$, light periods of 12 hour light and 12 hour darkness, and relative humidity of $45 \%$ ), fed with commercial feed (Topfeed Mills Company, Ilorin), and given tap water ad libitum. Full committee approval guiding experimental animals' use with an ethical number UERC/ASN/2015/120 was issued by the University of Ilorin Ethical Committee.

\section{Experimental Procedure}

The rats were randomly grouped and treated as follows: group I: control (un-ulcerated) rats administered distilled water only; group II: ulcerated rats administered distilled water only; group III: ulcerated rats administered $20 \mathrm{mg} / \mathrm{kg}$ b.w. omeprazole (reference drug); groups IV-VI: ulcerated rats administered 100,200 , and $400 \mathrm{mg} / \mathrm{kg}$ b.w. of ethanolic leaf extract of $A$. mexicana, respectively. Rats were fasted for 12 hours before the commencement of the experiment with access to water but later withdrawn 3 hours to the experiment. Rats were made ulcerated by $25 \mathrm{mg} / \mathrm{kg}$ b.w. indomethacin administered at a single dose orally and ulcer was confirmed on the third day by serum pepsinogen estimation. This was followed by the administration of omeprazole and the extract and lasted for 7 days.

\section{Preparation of Tissue Homogenates}

Rats were anesthetized under diethyl ether and the stomach ligated at both openings of the sphincter (lower esophageal and pyloric sphincters) and the gastric juice was collected for biochemical analysis. The stomach and duodenum were excised and separately homogenized in ice-cold sucrose solution $(0.25 \mathrm{M})$, and spun at $1,000 \times g$ for 10 minutes with a centrifuge (Model SM8 B, Surgrifriend Medicals, Essex, England). The supernatant was carefully removed with Pasteur pipettes into sample bottles and stored until further analysis.

Macroscopic Examination for Ulcer Index Determination The procedure highlighted in Gregory et a ${ }^{19}$ was employed to estimate the ulcer index (UI). The gastric juice in the stomach 
was first collected by ligation and the stomach was rinsed with normal saline. It was stretched and pinned on a board and examined macroscopically for gastric lesion using hand lens $(\times 20)$. The UI was calculated in $\mathrm{mm}^{2}$ using the expression:

Ulcer index $(\mathrm{UI})=$ Length $(\mathrm{mm}) \times$ Breadth $(\mathrm{mm})$ of lesion .

\section{Determination of Ulcer Indices}

The gastric juice was spun at $850 \times \mathrm{g}$ for 10 minutes and the content poured into a graduated measuring cylinder; this was taken as the volume of the gastric juice. ${ }^{9}$ The $\mathrm{pH}$ of the gastric juice was measured by placing a digital $\mathrm{pH}$ meter into the supernatant. The gastric acidity was determined according to a reported method. ${ }^{20}$ Briefly $0.5 \mathrm{~mL}$ of gastric content was titrated against $0.01 \mathrm{~N}$ sodium hydroxide, with the use of phenolphthalein as the indicator. The gastric acidity was expressed in milli-equivalent per liter $(\mathrm{mEq} / \mathrm{L})$.

$$
\text { Gastric acidity }=\frac{\text { Volume of } \mathrm{NaOH} \times 0.01 \mathrm{~N} \times 100}{\text { Volume of gastric juice }}
$$

\section{Pepsin Activity in Gastric Juice}

The procedure highlighted in Hirohashi et $\mathrm{al}^{21}$ was adopted to determine pepsin activity in the gastric juice. The pepsin activity was calculated from standard protein curve extrapolation.

\section{Determination of Glycoprotein Concentration}

Glycoprotein concentration in the gastric juice was expressed as a ratio of total carbohydrate (Tc) to total protein (Tp) as described by Nair. ${ }^{22}$

\section{Total Carbohydrates}

The Tc content in the stomach juice was estimated according to Nair. ${ }^{22}$ Briefly, $1 \mathrm{~mL}$ of $5 \%$ phenol was added to a separate test tube containing $0.15 \mathrm{~mL}$ of the juice and the blank (distilled water), respectively, and then shaken vigorously. An amount of $5 \mathrm{~mL}$ of $96 \% \mathrm{H}_{2} \mathrm{SO}_{4}$ was later introduced and mixed slowly. After 10 minutes, the test tubes were again shaken thoroughly and placed in a water bath at $30^{\circ} \mathrm{C}$ for 20 minutes. The absorbance was read at $482 \mathrm{~nm}$. A standard curve with different concentrations of glucose solution was prepared and the Tc in the gastric juice was expressed in micrograms per milliliter.

\section{Total Protein}

The protein content was measured according to a reported study by Lowry et al. ${ }^{23}$ Briefly $1 \mathrm{~mL}$ of stomach juice and $9 \mathrm{~mL}$ of $95 \%$ alcohol were mixed rigorously, and the mixture was spun at $3,000 \times g$ for 15 minutes to get a precipitate. Then to $0.1 \mathrm{~mL}$ of the alcohol precipitate, $1 \mathrm{~mL}$ of $0.1 \mathrm{~N}$ sodium hydroxide and $0.9 \mathrm{~mL}$ of distilled water were added. An amount of $0.4 \mathrm{~mL}$ was taken out of the mixture into another test tube and $4 \mathrm{~mm}$ of Biuret reagent was added and allowed to stand for 10 minutes. Then $0.4 \mathrm{~mL}$ of phenol reagent was later introduced and allowed to stand for 10 minutes to ensure color development. Absorbance was measured at $610 \mathrm{~nm}$ against a blank made with distilled water. The protein content was extrapolated from a standard protein curve prepared with bovine albumin and expressed in micrograms per milliliter. The glycoprotein concentration was expressed as:

$$
\text { Glycoprotein }=\frac{\text { Total Carbohydrate }}{\text { Total Protein }}
$$

\section{Determination of $\mathbf{H}^{+} \mid \mathrm{K}^{+}$-ATPase Activity}

The activity of $\mathrm{H}^{+} / \mathrm{K}^{+}$-ATPase in the gastric mucosa was expressed as nmol of Pi liberated/min/mg protein, which was assayed according to the procedure of Reyes-Chilpa et al. ${ }^{24}$

\section{Adherent Gastric Mucus Content}

The adherent gastric mucus content in the stomach was determined following a reported study. ${ }^{25}$ Glandular segments of the stomach were excised and weighed. Each segment was placed into $10 \mathrm{~mL} 0.1 \% \mathrm{w} / \mathrm{v}$ Alcian blue solution (in $10 \mathrm{~mL}$ of $0.16 \mathrm{M}$ sucrose solution, buffered with $0.05 \mathrm{M}$ sodium acetate, $\mathrm{pH} 5$ ). Following immersion for 2 hours, excess dye was removed by successively rinsing twice with $10 \mathrm{~mL}$ of $0.25 \mathrm{M}$ sucrose, first for 15 minutes then later for 45 minutes. The dye complexed with stomach wall mucus was extracted with $10 \mathrm{~mL}$ of $0.5 \mathrm{M} \mathrm{MgCl}_{2}$ with intermittent shaking for 1 minute at 30-minute intervals for 2 hours. Then $4 \mathrm{~mL}$ of the Alcian blue extract was added with an equal volume of diethyl ether and shaken vigorously. The emulsion obtained was spun at $725 \times g$ for 10 minutes and the absorbance of an aqueous layer formed was read at $580 \mathrm{~nm}$. Values were compared with the Alcian blue concentration standard curve.

\section{Determination of Glutathione Concentration and Lipid Peroxidation}

Reduced GSH concentration and lipid peroxidation were determined in the stomach and duodenum of rats by employing the procedures of Ellman ${ }^{26}$ and Buege and Aust, ${ }^{27}$ respectively.

\section{Determination of Antioxidant Enzyme Status and Chromosomal Aberration}

SOD, catalase (CT), GSH-Red, GSH-Px, and GST activities in the stomach and duodenum were determined following methods reported in various studies..$^{28-32}$ The method described by Krause ${ }^{33}$ was adopted for chromosomal aberration analysis in the kidney and liver of rats.

\section{Data Analysis}

Data represent the mean of six replicates \pm standard error of mean. Data were analyzed statistically with GraphPad Prism 8.0 using one-way analysis of variance. Differences between group means were considered significant at $p<0.05$.

\section{Results}

\section{Phytochemical Screening}

The preliminary phytochemical screening revealed that phenolics, flavonoids, alkaloids, and saponins were present in the ethanolic leaf extract of A. mexicana. Alkaloids was the 
Table 1 Concentration of secondary metabolites of ethanolic leaf extract of $A$. mexicana

\begin{tabular}{|l|l|}
\hline Secondary metabolites & Concentration $(\mathrm{g} / 100 \mathrm{~g})$ \\
\hline Flavonoids & $10.77 \pm 0.03$ \\
\hline Phenolic & $4.84 \pm 0.02$ \\
\hline Saponins & $4.30 \pm 0.01$ \\
\hline Alkaloids & $14.67 \pm 0.02$ \\
\hline
\end{tabular}

Note: Values are \% mean of three determinations \pm SEM.

most predominant $(14.67 \pm 0.02 \mathrm{~g} / 100 \mathrm{~g})$ followed by flavonoids $(10.77 \pm 0.03 \mathrm{~g} / 100 \mathrm{~g})$, phenolics $(4.84 \pm 0.02)$, and saponins $(4.30 \pm 0.01 \mathrm{~g} / 100 \mathrm{~g}$ ) ( - Table 1 ). There was a significant upsurge $(p<0.05)$ in the UI of ulcerated rats when compared with the control (nonulcerated). Administration of 100,200 , and $400 \mathrm{mg} / \mathrm{kg}$ b.w. of the crude extract caused a reduction of $\mathrm{UI}$ in rats, with a better reduction of the ulcer lesion in the group treated with $200 \mathrm{mg} / \mathrm{kg}$ b.w. when compared with the untreated ulcerated group. This reduction in UI of rats treated with $200 \mathrm{mg} / \mathrm{kg}$ b.w. was not significantly different when compared with the reference drug (-Table 2).

The gastric volume, gastric acidity, $\mathrm{H}^{+} / \mathrm{K}^{+}$-ATPase and pepsin activities increased significantly $(p<0.05)$ while the $\mathrm{pH}$ reduced significantly in ulcerated rats compared with the control. However, $200 \mathrm{mg} / \mathrm{kg}$ b.w. of the extract was most effective in reducing the gastric acidity and gastric acid volume of the rats. Also the extract at $200 \mathrm{mg} / \mathrm{kg}$ b.w. significantly $(p<0.05)$ increased the gastric $\mathrm{pH}$ of rats to $\mathrm{pH}$ value similar to the omeprazole-treated group (-Table 2 ). Similarly, it was observed that $200 \mathrm{mg} / \mathrm{kg}$ b.w. extract of $A$. mexicana administered to rats significantly $(p<0.05)$ attenuated the activities of $\mathrm{H}^{+} / \mathrm{K}^{+}$-ATPase, also known as proton pump (-Table 3 ), and pepsin ( - Fig. 1) close to the values of the control and omeprazole-treated groups. Tc concentration and glycoprotein content (Tc:Tp) significantly $(p<0.05)$ reduced in the stomach juice of ulcerated rats that received no medical intervention in comparison with the control ( - Table 4). A similar reduction was also noticed in the adherent mucus content of ulcerated rats when compared with the control (-Fig. 2); however, the
Table 3 Effect of administration of ethanolic leaf extract of $A$. mexicana on gastric $\mathrm{H}^{+} / \mathrm{K}^{+}$-ATPase activity of indomethacininduced ulcerated rats

\begin{tabular}{|l|l|}
\hline Treatment groups & $\begin{array}{l}\mathrm{H}^{+} / \mathrm{K}^{+} \text {-ATPase activity } \\
\text { (nmol/min/mg protein) }\end{array}$ \\
\hline Control (distilled water) & $4.60 \pm 0.19^{\mathrm{a}}$ \\
\hline Ulcerated rats & $9.61 \pm 0.24^{\mathrm{b}}$ \\
\hline $\begin{array}{l}\text { Ulcerated rats }+20 \mathrm{mg} / \mathrm{kg} \text { b.w. } \\
\text { omeprazole }\end{array}$ & $4.84 \pm 0.11^{\mathrm{a}}$ \\
\hline $\begin{array}{l}\text { Ulcerated rats }+100 \mathrm{mg} / \mathrm{kg} \text { b.w. } \\
\text { extract }\end{array}$ & $5.24 \pm 0.42^{\mathrm{c}}$ \\
\hline $\begin{array}{l}\text { Ulcerated rats }+200 \mathrm{mg} / \mathrm{kg} \text { b.w. } \\
\text { extract }\end{array}$ & $4.79 \pm 0.14^{\mathrm{a}}$ \\
\hline $\begin{array}{l}\text { Ulcerated rats }+400 \mathrm{mg} / \mathrm{kg} \text { b.w. } \\
\text { extract }\end{array}$ & $7.90 \pm 0.62^{\mathrm{d}}$ \\
\hline
\end{tabular}

Abbreviations: b.w., body weight; SEM, standard error of mean. Note: Data are mean of six determinations \pm SEM. Values having different alphabets down the column for each parameter show significant difference $(p<0.05)$.

ethanolic extract of $A$. mexicana leaves at the investigated doses significantly $(p<0.05)$ enhanced the glycoprotein and mucus contents upon administration in the ulcerated group with $200 \mathrm{mg} / \mathrm{kg}$ b.w., showing better efficacy in comparison with the omeprazole-treated group, with no significant difference observed.

\section{Antioxidant Enzyme Status}

The antioxidant enzyme status data in the stomach and duodenum of ulcerated rats are presented in - Tables 5 and 6 and -Figs. 3 and 4. SOD (-Fig. 3) and CT (-Fig. 4) activities significantly $(p<0.05)$ decreased in the stomach and duodenum of ulcerated rats compared with the control. In the same vein, a significant decrease $(p<0.05)$ in activity of thiol antioxidant enzymes (GSH-Red, GSH-px, and GST) was observed in both tissues of untreated rats when compared with the control ( - Tables $\mathbf{5}$ and $\mathbf{6}$ ). It was noticed that $200 \mathrm{mg} / \mathrm{kg}$ b.w. of the extract effectively ameliorated the enzyme (CT, SOD, GSH-Red, GSH-px, and GST) activity which was initially depleted in both tissues of the ulcerated

Table 2 Effect of administration of ethanolic leaf extract of $A$. mexicana on gastric juice secretory parameters of indomethacininduced ulcerated rats

\begin{tabular}{|c|c|c|c|c|}
\hline \multirow[t]{2}{*}{ Treatment groups } & \multicolumn{4}{|c|}{ Gastric juice secretory parameters } \\
\hline & $\begin{array}{l}\text { Ulcer Index } \\
\left(\mathrm{mm}^{2}\right)\end{array}$ & $\begin{array}{l}\text { Gastric volume } \\
(\mathrm{mL})\end{array}$ & $\mathrm{pH}$ & $\begin{array}{l}\text { Gastric acidity } \\
\text { (mEq/L) }\end{array}$ \\
\hline Control (distilled water) & - & $1.86 \pm 0.08^{a}$ & $4.25 \pm 0.10^{\mathrm{a}}$ & $3.36 \pm 0.03^{a}$ \\
\hline Ulcerated rats & $6.45 \pm 0.09^{\mathrm{a}}$ & $5.45 \pm 0.25^{b}$ & $2.43 \pm 0.01^{b}$ & $8.44 \pm 0.39^{b}$ \\
\hline Ulcerated rats $+20 \mathrm{mg} / \mathrm{kg}$ b.w. omeprazole & $2.79 \pm 0.04^{b}$ & $1.99 \pm 0.07^{\mathrm{a}}$ & $3.77 \pm 0.19^{c}$ & $3.49 \pm 0.05^{\mathrm{a}}$ \\
\hline Ulcerated rats $+100 \mathrm{mg} / \mathrm{kg}$ b.w. extract & $4.20 \pm 0.14^{c}$ & $3.28 \pm 0.14^{c}$ & $3.58 \pm 0.12^{c}$ & $5.39 \pm 0.14^{c}$ \\
\hline Ulcerated rats $+200 \mathrm{mg} / \mathrm{kg}$ b.w. extract & $2.81 \pm 0.12^{b}$ & $1.90 \pm 0.15^{\mathrm{a}}$ & $3.85 \pm 0.27^{c}$ & $3.33 \pm 0.15^{\mathrm{a}}$ \\
\hline Ulcerated rats $+400 \mathrm{mg} / \mathrm{kg}$ b.w. extract & $3.07 \pm 0.07^{\mathrm{d}}$ & $2.77 \pm 0.22^{\mathrm{d}}$ & $3.49 \pm 0.08^{c}$ & $4.39 \pm 0.20^{c}$ \\
\hline
\end{tabular}

Abbreviations: b.w., body weight; SEM, standard error of mean.

Note: Data are mean of six determinations \pm SEM. Values having different alphabets down the column for each parameter show significant difference $(p<0.05)$. 


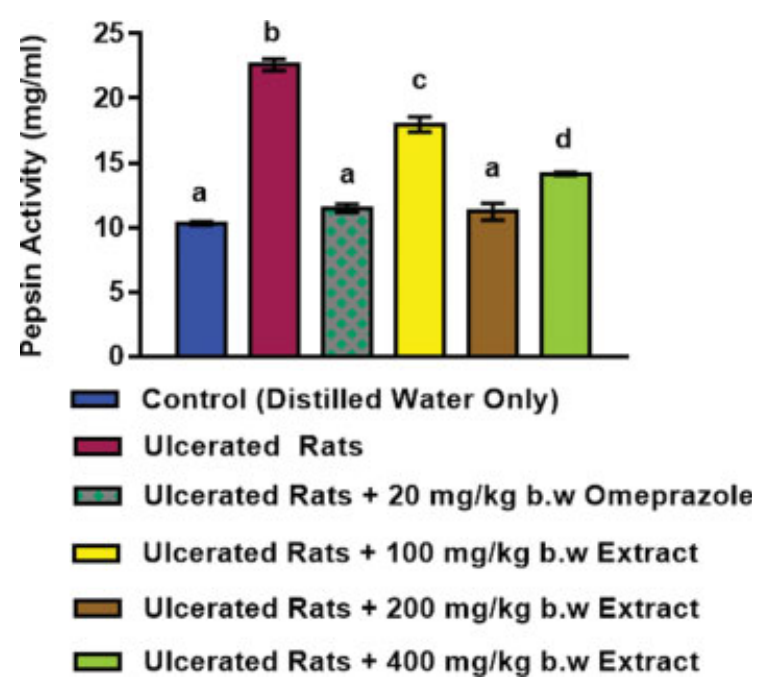

Fig. 1 Effect of administration of ethanolic leaf extract of $A$. mexicana on gastric pepsin activity of indomethacin-induced ulcerated rats. Values are mean of six determinations \pm SEM. Bars with different alphabets are significantly different $(p<0.05)$ from each other. SEM, standard error of mean.

untreated rats and this was comparable with the reference drug (omeprazole).

\section{Glutathione and Malondialdehyde Concentrations}

The concentration of GSH decreased significantly $(p<0.05)$, whereas the concentration of the lipid peroxidation product (malondialdehyde [MDA]) increased significantly in the stomach and duodenum of ulcerated rats that received no medical attention when compared with the distilled water group (control). The level of reduced GSH improved significantly $(p<0.05)$ in both tissues of ulcerated rats treated with the doses of the extract (-Table 5), while the MDA concentration significantly $(p<0.05)$ reduced after treatment with the different doses of the extract (-Fig. 5) however; $200 \mathrm{mg} / \mathrm{kg}$ b.w. of the extract was most effective in ameliorating the alterations in GSH and MDA concentrations.

\section{Macroscopic View}

The macroscopic view of the gastric mucosa of ulcerated rats administered ethanolic leaf extract of $A$. mexicana is depicted

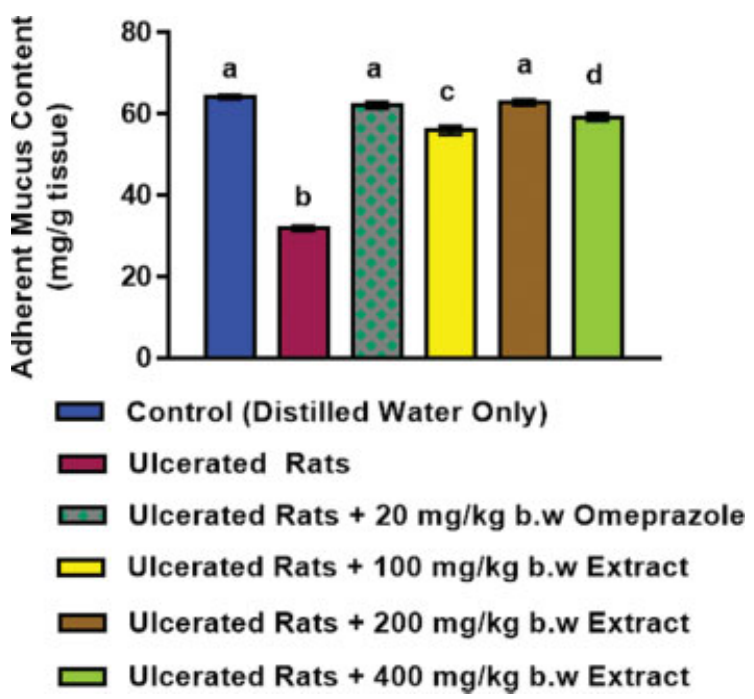

Fig. 2 Effect of administration of ethanolic leaf extract of $A$. mexicana on adherent mucus content of indomethacin-induced ulcerated rats. Values are mean of six determinations \pm SEM. Bars with different alphabets are significantly different $(p<0.05)$ from each other. SEM, standard error of mean.

-Fig. 6. Total ulceration evident with severe injury was seen to have appeared in the gastric pits of ulcerated rats without medical attention (Fig. 6b), but a mild amelioration of the gastric pit was observed in the gastric mucosa of rats that received $100 \mathrm{mg} / \mathrm{kg}$ b.w. of the extract as medical intervention (-Fig. 6d) when compared with the untreated group (Fig. 6b), whereas $200 \mathrm{mg} / \mathrm{kg}$ b.w. of the extract (-Fig. 6e) effectively ameliorated the ulcerated gastric mucosa of rats in a manner similar to that observed for the reference-drug-treated group

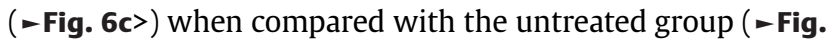
6b). The gastric mucosa of rats that received $400 \mathrm{mg} / \mathrm{kg}$ b.w. of the extract as medical intervention also showed a promising ulcer lesion amelioration (- Fig. $6 \mathbf{f}$ ).

\section{Macroscopic View}

- Tables $\mathbf{7}$ and $\mathbf{8}$ depict the rate of chromosomal aberration in the liver and kidney of ulcerated rats respectively following treatment of rats with the extract at the three doses investigated. A significant upsurge $(p<0.05)$ in the frequencies of chromosomal aberration was observed in the liver and kidney

Table 4 Effect of administration of ethanolic leaf extract of A. mexicana on glycoprotein concentration in gastric juice of indomethacin-induced ulcerated rats

\begin{tabular}{|l|l|l|l|}
\hline Treatment groups & Total CHO $(\mu \mathrm{g} / \mathrm{mL})$ & Total protein $(\mu \mathrm{g} / \mathrm{mL})$ & $\begin{array}{l}\text { Total CHO:total protein } \\
(\mathrm{glycoprotein})(\mu \mathrm{g} / \mathrm{mL})\end{array}$ \\
\hline Control (distilled water) & $66.33 \pm 0.61^{\mathrm{a}}$ & $31.89 \pm 0.10^{\mathrm{a}}$ & $2.08 \pm 0.02^{\mathrm{a}}$ \\
\hline Ulcerated rats & $35.62 \pm 0.10^{\mathrm{b}}$ & $41.70 \pm 0.26^{\mathrm{b}}$ & $0.85 \pm 0.01^{\mathrm{b}}$ \\
\hline Ulcerated rats $+20 \mathrm{mg} / \mathrm{kg}$ b.w. omeprazole & $65.04 \pm 0.21^{\mathrm{a}}$ & $32.63 \pm 0.23^{\mathrm{a}}$ & $2.01 \pm 0.02^{\mathrm{a}}$ \\
\hline Ulcerated rats $+100 \mathrm{mg} / \mathrm{kg}$ b.w. extract & $58.05 \pm 0.21^{\mathrm{c}}$ & $31.10 \pm 0.01^{\mathrm{a}}$ & $1.87 \pm 0.01^{\mathrm{c}}$ \\
\hline Ulcerated rats $+200 \mathrm{mg} / \mathrm{kg}$ b.w. extract & $66.93 \pm 0.01^{\mathrm{a}}$ & $32.84 \pm 0.01^{\mathrm{a}}$ & $2.04 \pm 0.01^{\mathrm{a}}$ \\
\hline Ulcerated rats $+400 \mathrm{mg} / \mathrm{kg}$ b.w. extract & $62.81 \pm 0.01^{\mathrm{d}}$ & $30.32 \pm 0.14^{\mathrm{a}}$ & $2.07 \pm 0.01^{\mathrm{a}}$ \\
\hline
\end{tabular}

Abbreviations: b.w., body weight; SEM, standard error of mean.

Note: Data are mean of six determinations \pm SEM. Values having different alphabets down the column for each parameter show significant difference $(p<0.05)$. 
Table 5 Effect of administration of ethanolic leaf extract of $A$. mexicana on reduced glutathione concentration and glutathione peroxidase activity in the stomach and duodenum of indomethacin-induced ulcerated rats

\begin{tabular}{|c|c|c|c|c|}
\hline \multirow[t]{2}{*}{ Treatment groups } & \multicolumn{2}{|c|}{$\begin{array}{l}\text { Reduced glutathione } \\
\text { (nmol/mg protein) }\end{array}$} & \multicolumn{2}{|c|}{$\begin{array}{l}\text { Glutathione peroxidase } \\
\text { (nmol/mg protein) }\end{array}$} \\
\hline & Stomach & Duodenum & Stomach & Duodenum \\
\hline Control (distilled water) & $8.86 \pm 0.14^{\mathrm{a}}$ & $8.20 \pm 0.34^{\mathrm{a}}$ & $0.45 \pm 0.03^{\mathrm{a}}$ & $0.37 \pm 0.03^{\mathrm{a}}$ \\
\hline Ulcerated rats & $2.47 \pm 0.19^{\mathrm{b}}$ & $1.46 \pm 0.12^{\mathrm{b}}$ & $0.20 \pm 0.01^{\mathrm{b}}$ & $0.14 \pm 0.01^{\mathrm{b}}$ \\
\hline Ulcerated rats $+20 \mathrm{mg} / \mathrm{kg}$ b.w. omeprazole & $6.98 \pm 0.15^{c}$ & $7.61 \pm 0.10^{c}$ & $0.40 \pm 0.02^{\mathrm{a}}$ & $0.40 \pm 0.03^{\mathrm{a}}$ \\
\hline Ulcerated rats $+100 \mathrm{mg} / \mathrm{kg}$ b.w. extract & $4.10 \pm 0.26^{d}$ & $3.69 \pm 0.13^{d}$ & $0.18 \pm 0.01^{\mathrm{b}}$ & $0.27 \pm 0.01^{c}$ \\
\hline Ulcerated rats $+200 \mathrm{mg} / \mathrm{kg}$ b.w. extract & $8.40 \pm 0.32^{\mathrm{a}}$ & $7.51 \pm 0.12^{c}$ & $0.44 \pm 0.03^{\mathrm{a}}$ & $0.41 \pm 0.03^{\mathrm{a}}$ \\
\hline Ulcerated rats $+400 \mathrm{mg} / \mathrm{kg}$ b.w. extract & $5.34 \pm 0.13^{\mathrm{e}}$ & $6.80 \pm 0.04^{\mathrm{e}}$ & $0.34 \pm 0.02^{c}$ & $0.30 \pm 0.02^{c}$ \\
\hline
\end{tabular}

Abbreviations: b.w., body weight; SEM, standard error of mean.

Note: Data are mean of six determinations \pm SEM. Values having different alphabets down the column for each parameter show significant difference $(p<0.05)$.

Table 6 Effect of administration of ethanolic leaf extract of $A$. mexicana on glutathione reductase and glutathione-S-transferase activities in the stomach and duodenum of indomethacin-induced ulcerated rats

\begin{tabular}{|c|c|c|c|c|}
\hline \multirow[t]{2}{*}{ Treatment groups } & \multicolumn{2}{|c|}{$\begin{array}{l}\text { Glutathione reductase } \\
\text { (nmol/mg protein) }\end{array}$} & \multicolumn{2}{|c|}{$\begin{array}{l}\text { Glutathione-s-transferase } \\
\text { (nmol/mg protein) }\end{array}$} \\
\hline & Stomach & Duodenum & Stomach & Duodenum \\
\hline Control (distilled water) & $28.42 \pm 0.11^{\mathrm{a}}$ & $9.49 \pm 0.05^{\mathrm{a}}$ & $14.24 \pm 0.18^{a}$ & $4.49 \pm 0.02^{\mathrm{a}}$ \\
\hline Ulcerated rats & $13.76 \pm 0.28^{b}$ & $4.63 \pm 0.22^{b}$ & $7.45 \pm 0.25^{b}$ & $2.32 \pm 0.02^{b}$ \\
\hline Ulcerated rats $+20 \mathrm{mg} / \mathrm{kg}$ b.w. omeprazole & $26.60 \pm 0.39^{c}$ & $9.30 \pm 0.05^{\mathrm{a}}$ & $13.58 \pm 0.04^{c}$ & $4.20 \pm 0.22^{\mathrm{a}}$ \\
\hline Ulcerated rats $+100 \mathrm{mg} / \mathrm{kg}$ b.w. extract & $21.33 \pm 0.71^{d}$ & $6.22 \pm 0.18^{c}$ & $9.56 \pm 0.09^{d}$ & $3.52 \pm 0.16^{c}$ \\
\hline Ulcerated rats $+200 \mathrm{mg} / \mathrm{kg}$ b.w. extract & $27.98 \pm 0.23^{c}$ & $9.33 \pm 0.08^{\mathrm{a}}$ & $14.20 \pm 0.15^{\mathrm{a}}$ & $4.32 \pm 0.20^{\mathrm{a}}$ \\
\hline Ulcerated rats $+400 \mathrm{mg} / \mathrm{kg}$ b.w. extract & $25.49 \pm 0.18^{\mathrm{e}}$ & $8.49 \pm 0.06^{d}$ & $11.28 \pm 0.22^{\mathrm{e}}$ & $3.69 \pm 0.14^{c}$ \\
\hline
\end{tabular}

Abbreviations: b.w., body weight; SEM, standard error of mean.

Note: Data are mean of six determinations \pm SEM. Values having different alphabets down the column for each parameter show significant difference $(p<0.05)$.

of rats that received the highest dose $(400 \mathrm{mg} / \mathrm{kg} \mathrm{b.w.)} \mathrm{of} \mathrm{the}$ extract as medical intervention when compared with the control. This increase in frequencies of chromosomal aberration observed in this group was not significantly $(p>0.05)$ different when compared with the ulcerated group that received no medical attention. Conversely, rats administered 100 and $200 \mathrm{mg} / \mathrm{kg}$ b.w. ethanolic leaf extract of $A$. mexicana showed no significant alteration or change $(p>0.05)$ in the frequencies of chromosomal aberration both in the liver ( $\mathbf{- T a b l e ~ 7 )}$ ) and kidney ( $\mathbf{- T a b l e ~ 8 )}$ ) of rats when compared with the control.

\section{Discussion}

Alkaloids, flavonoids, saponins, and phenolics, which are the phytoconstituents identified in the ethanolic leaf extract of A. mexicana, have also been reported by Perumal et al. ${ }^{34}$ These secondary metabolites have demonstrated antiulcerogenic activities by different mechanisms and are well documented in the literature. ${ }^{35-38}$

The ulcer model used in this study has widely been employed. ${ }^{39,40}$ Indomethacin used to induce ulcer in this study is a therapeutic agent whose involvement in ulcer formation is by inducing uncontrolled gastric acid production and diminishing the gastric mucosa defense system. ${ }^{41}$ It also acts by inhibiting cyclooxygenase II enzyme which subsequently sup- presses prostaglandin (a key metabolite that protect the stomach from the corrosive effect of gastric acid) synthesis and epithelial cell proliferation. ${ }^{42}$ In addition, indomethacin has been reported to show involvement in the production of free radicals that alter the permeability of the gastric mucus and eventually cause its depletion in the mucosa. ${ }^{43,44}$

Gastric acidity, volume, $\mathrm{pH}$, and UI are indices of ulceration. Alteration in the concentration of these indices (i.e., an increase in gastric acidity, volume, UI, and low $\mathrm{pH}$ ) usually indicates ulceration in the gastrointestinal mucosal membrane. The alterations observed in the concentration of these indices in the indomethacin-induced ulcerated group that received no medical intervention may be due to the fact that indomethacin caused an imbalance between gastric defensive factors and the aggressive factors by inhibiting cyclooxygenase enzyme. Correlations between gastric acidity, gastric volume, $\mathrm{pH}$, and $\mathrm{UI}$ in the ulcerative state have been established. ${ }^{45}$ Also UI, gastric volume, and $\mathrm{pH}$ are reflective of gastric acidity. The higher the gastric acidity, the higher are the gastric volume and UI (degree of ulceration), and the lower the gastric $\mathrm{pH}$.

Mahmoud et $\mathrm{al}^{46}$ established that gastric ulcer is usually accompanied by an elevated level of gastric acidity, volume, and low pH, and this is evident in this study (-Table $\mathbf{2}$ ). The significant increase in UI, gastric volume, acidity, and low $\mathrm{pH}$ of ulcerated rats after administering indomethacin is in 


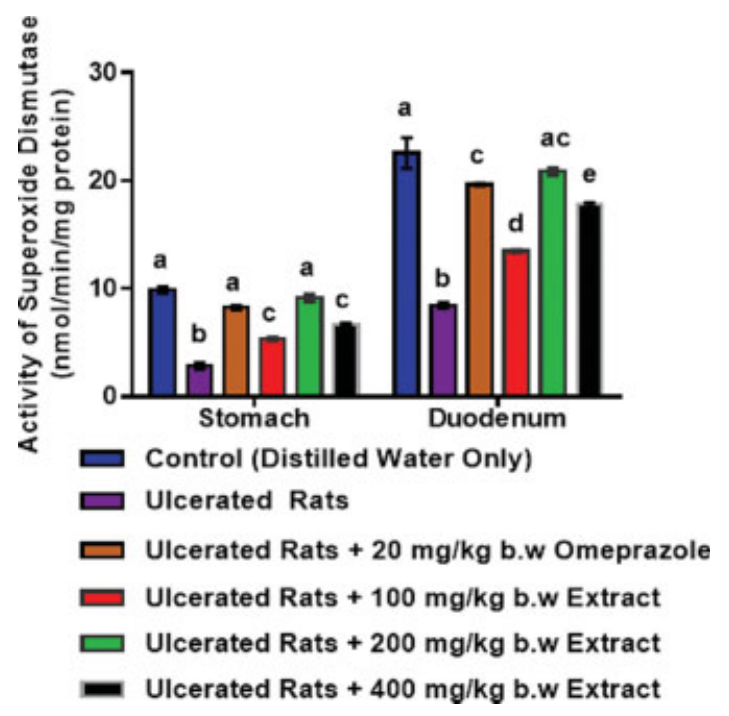

Fig. 3 Effect of administration of ethanolic leaf extract of $A$. mexicana on superoxide dismutase activity in the stomach and duodenum of indomethacin-induced ulcerated rats. Values are mean of six determinations \pm SEM. Bars with different alphabets are significantly different $(p<0.05)$ from each other. SEM, standard error of mean.

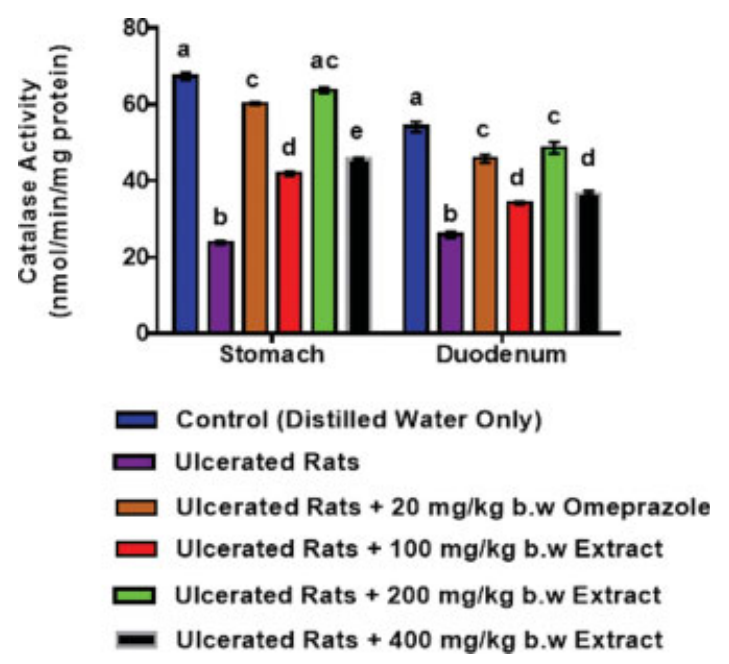

Fig. 4 Effect of administration of ethanolic leaf extract of $A$. mexicana on catalase activity in the stomach and duodenum of indomethacininduced ulcerated rats. Values are mean of six determinations \pm SEM. Bars with different alphabets are significantly different $(p<0.05)$ from each other. SEM, standard error of mean.

consonance with the findings of various studies ${ }^{47-49}$ where indomethacin caused alterations in the level of these indices.

The significant decrease in the concentration of glycoprotein and depletion in mucus content seen in ulcerated rats may also be attributed to the imbalance between the defensive factors and aggressive factors which resulted from indomethacin administration. Gastric $\mathrm{H}^{+} / \mathrm{K}^{+}$-ATPase is an enzyme or proton pump found in the apical parietal cell membrane mainly responsible for acidification of the stomach content. The increase in the activities of the pump and pepsin may indicate that indomethacin caused the activation of the proton pump enzyme leading to excessive gastric acid output and subsequently increasing pepsin activity since acidification is

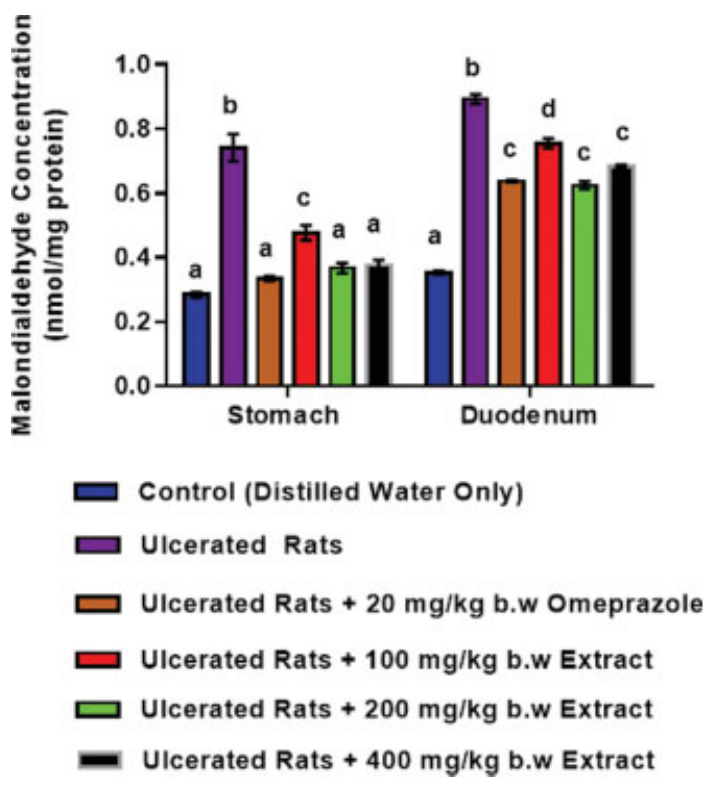

Fig. 5 Effect of administration of ethanolic leaf extract of $A$. mexicana on malondialdehyde concentration in the stomach and duodenum of indomethacin-induced ulcerated rats. Values are mean of six determinations \pm SEM. Bars with different alphabets are significantly different $(p<0.05)$ from each other. SEM, standard error of mean.

required for activation of pepsin in the stomach..$^{50}$ The ability of the extract particularly at $200 \mathrm{mg} / \mathrm{kg}$ b.w. to effectively attenuate the ulcer indices and enhance the mucus content is an evidence that the extract restored normalcy or equilibrium between the aggressive factors and defensive factors probably facilitated by the phytoconstituents acting either individually or synergistically. The extract was also able to lower the activities of the proton pump and pepsin thus suggesting its inhibitory role in the signaling pathway that leads to the activation of the proton pump and the release of pepsin from the acidification process in the stomach.

Alkaloids are known to inhibit lesions in the ulcerative state by altering acid secretion via increasing luminal gastric discharge of basal bicarbonate and $\mathrm{pH}$. Also flavonoids and saponins have been reported to stimulate mucus production and counteract the deteriorating effects of reactive oxidants in the gastrointestinal tract. ${ }^{51,52}$

Oxidative stress is known to be involved in the pathogenesis of ulcer, ${ }^{53,54}$ but antioxidant enzymes serve as the first line of defense against oxidative stress in the gastric mucosal membrane, this necessitates the need in this study to check the antioxidant status. The decrease in antioxidant enzyme (SOD, CT, GSH-Red, GSH-px, and GST) activity in the stomach and duodenum of rats is an indication of imbalance between pro-oxidants and antioxidant status caused by the administration of indomethacin since there is a correlation between oxidative stress and ulceration caused by indomethacin, ${ }^{54}$ or may indicate increased oxidative stress in the tissues of the ulcerated rats. The amelioration of the depleted antioxidant enzymes following treatment of rats with the extract, which was particularly more pronounced in rats treated with 200 $\mathrm{mg} / \mathrm{kg}$ b.w., may have been facilitated by flavonoids as an antioxidant booster. Therefore, flavonoids among other 
A

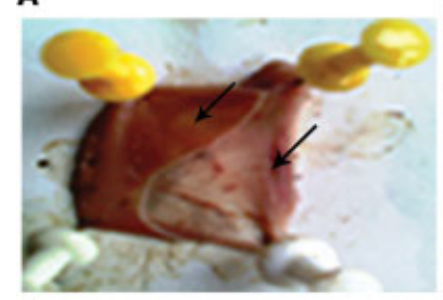

D

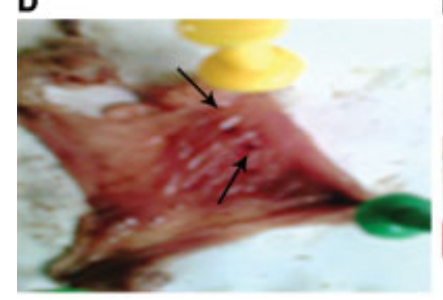

B

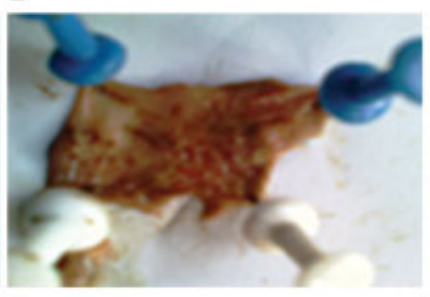

$\mathbf{E}$

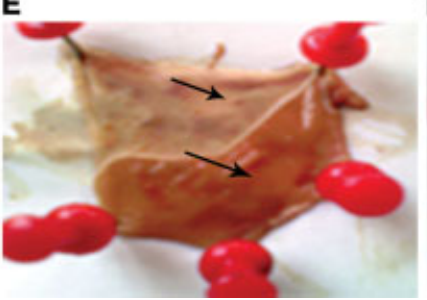

C

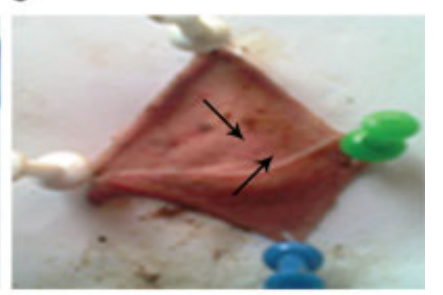

$\mathbf{F}$

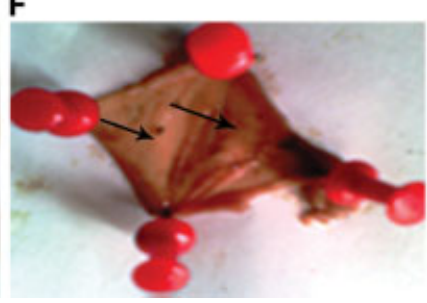

Fig. 6 Macroscopic appearance of gastric mucosa of ulcerated rat treated with or without b.w ethanolic leaf extract of $A$. mexicana $(\times 10)$. $($ A $)$ The gastric mucosa of rats in control group. The arrows depict the normal flattening of gastric mucosa with no injuries observed. (B) The gastric mucosa of ulcerated rat induced by indomethacin; (C) The gastric mucosa of ulcerated rats administered with $20 \mathrm{mg} / \mathrm{kg}$ b.w omeprazole. The arrows depict an ameliorated injury of the gastric mucosa. (D) The gastric mucosa of ulcerated rats administered with $100 \mathrm{mg} / \mathrm{kg}$ b.w omeprazole. The arrows depict mild ameliorated injuries of the gastric mucosa. (E) The gastric mucosa of ulcerated rat administered with $200 \mathrm{mg} / \mathrm{kg}$ b.w ethanolic leaf extract of $A$. mexicana. The arrows depict a well enhanced ameliorated gastric mucosa injuries and flattening of the gastric mucosa. (F) The gastric mucosa of ulcerated rat administered with $400 \mathrm{mg} / \mathrm{kg}$ b.w ethanolic leaf extract of $A$. mexicana. The arrows indicate mild ameliorated gastric mucosa injuries.

Table 7 Effect of administration of ethanolic leaf extract of $A$. mexicana on chromosomal aberration in the liver of indomethacininduced ulcerated rats

\begin{tabular}{|l|l|l|l|l|}
\hline Treatment groups & TNMA & MCA & MI & \% CA \\
\hline Control (distilled water) & $143.00 \pm 11.00^{\mathrm{a}}$ & $2.00 \pm 1.00^{\mathrm{a}}$ & $27.80 \pm 1.00^{\mathrm{a}}$ & $1.85 \pm 0.47^{\mathrm{a}}$ \\
\hline Ulcerated rats & $143.00 \pm 12.00^{\mathrm{a}}$ & $36.55 \pm 1.50^{\mathrm{b}}$ & $29.20 \pm 0.70^{\mathrm{a}}$ & $42.10 \pm 1.20^{\mathrm{b}}$ \\
\hline Ulcerated rats $+20 \mathrm{mg} / \mathrm{kg}$ b.w. omeprazole & $139.00 \pm 10.00^{\mathrm{a}}$ & $2.10 \pm 2.00^{\mathrm{a}}$ & $26.90 \pm 2.20^{\mathrm{a}}$ & $2.20 \pm 0.00^{\mathrm{a}}$ \\
\hline Ulcerated rats $+100 \mathrm{mg} / \mathrm{kg}$ b.w. extract & $142.00 \pm 9.00^{\mathrm{a}}$ & $3.00 \pm 1.00^{\mathrm{a}}$ & $28.00 \pm 1.30^{\mathrm{a}}$ & $2.40 \pm 0.20^{\mathrm{a}}$ \\
\hline Ulcerated rats $+200 \mathrm{mg} / \mathrm{kg}$ b.w. extract & $138.00 \pm 10.00^{\mathrm{a}}$ & $2.20 \pm 1.50^{\mathrm{a}}$ & $27.70 \pm 1.20^{\mathrm{a}}$ & $1.90 \pm 1.00^{\mathrm{a}}$ \\
\hline Ulcerated rats $+400 \mathrm{mg} / \mathrm{kg}$ b.w. extract & $139.00 \pm 12.00^{\mathrm{a}}$ & $32.50 \pm 1.70^{\mathrm{b}}$ & $29.10 \pm 0.90^{\mathrm{a}}$ & $39.57 \pm 2.50^{\mathrm{b}}$ \\
\hline
\end{tabular}

Abbreviations: b.w., body weight; \% CA, percentage of chromosomal aberration; MCA, mitotic chromosomal aberration; MI, mitotic index; TNMA, total number of mitotic.

Note: Data are mean of three determinations \pm SEM. Values having different alphabets down the column for each parameter show significant difference $(p<0.05)$.

Table 8 Effect of administration of ethanolic leaf extract of $A$. mexicana on chromosomal aberration in the kidney of indomethacininduced ulcerated rats

\begin{tabular}{|l|l|l|l|l|}
\hline Treatment groups & TNMA & MCA & MI & \% CA \\
\hline Control (distilled water) & $156.00 \pm 2.00^{\mathrm{a}}$ & $2.00 \pm 1.20^{\mathrm{a}}$ & $17.20 \pm 0.20^{\mathrm{a}}$ & $2.24 \pm 1.20^{\mathrm{a}}$ \\
\hline Ulcerated rats & $149.00 \pm 4.00^{\mathrm{a}}$ & $34.45 \pm 2.20^{\mathrm{b}}$ & $15.17 \pm 0.60^{\mathrm{a}}$ & $41.26 \pm 0.40^{\mathrm{b}}$ \\
\hline Ulcerated rats $+20 \mathrm{mg} / \mathrm{kg}$ b.w. omeprazole & $151.00 \pm 2.50^{\mathrm{a}}$ & $3.00 \pm 2.00^{\mathrm{a}}$ & $16.58 \pm 0.35^{\mathrm{a}}$ & $3.02 \pm 0.68^{\mathrm{a}}$ \\
\hline Ulcerated rats $+100 \mathrm{mg} / \mathrm{kg}$ b.w. extract & $153.00 \pm 2.50^{\mathrm{a}}$ & $3.00 \pm 2.00^{\mathrm{a}}$ & $16.60 \pm 0.20^{\mathrm{a}}$ & $3.00 \pm 0.72^{\mathrm{a}}$ \\
\hline Ulcerated rats $+200 \mathrm{mg} / \mathrm{kg}$ b.w. extract & $146.50 \pm 4.00^{\mathrm{a}}$ & $2.00 \pm 1.20^{\mathrm{a}}$ & $15.58 \pm 1.54^{\mathrm{a}}$ & $2.20 \pm 0.98^{\mathrm{a}}$ \\
\hline Ulcerated rats $+400 \mathrm{mg} / \mathrm{kg}$ b.w. extract & $157.00 \pm 2.00^{\mathrm{a}}$ & $32.20 \pm 2.50^{\mathrm{b}}$ & $17.10 \pm 0.40^{\mathrm{a}}$ & $39.55 \pm 4.50^{\mathrm{b}}$ \\
\hline
\end{tabular}

Abbreviations: b.w., body weight; \% CA, percentage of chromosomal aberration; MCA, mitotic chromosomal aberration; MI, mitotic index; TNMA, total number of mitotic.

Note: Data are mean of three determinations \pm SEM. Values having different alphabets down the column for each parameter show significant difference $(p<0.05)$.

components may be responsible for the antiulcerogenic activity exhibited by the ethanolic extract of $A$. mexicana.

The microscopic view of the gastric mucosal membrane of rats treated with $200 \mathrm{mg} / \mathrm{kg}$ b.w. of the extract which showed completely ameliorated injury or damage of the gastric mucosal membrane could indicate wound healing activity of the extract. This was consistent with Dash and Murthy's earlier suggestions of the wound healing activity of $A$. mexicana. ${ }^{55}$ 
The concentration of MDA, a product of lipid peroxidation, which increased significantly in ulcerated rats, is also an indicator of increased oxidative stress resulting from production of MDA via lipid peroxidation in the gastric mucosal membrane. It has been reported that free radicals overwhelm antioxidant enzyme activity and activate lipid deterioration, a process in the toxicity mechanism of indomethacin. ${ }^{56}$ From this study, ethanolic leaf extract of A. mexicana at a dose of $200 \mathrm{mg} / \mathrm{kg}$ b.w. was more efficacious against indomethacin-induced ulceration in rats than the other two doses (100 and $400 \mathrm{mg} / \mathrm{kg}$ b.w.), investigated by attenuating the gastric acidity, gastric volume, pepsin, and $\mathrm{H}^{+} / \mathrm{K}^{+}$-ATPase activities, improved the gastric mucus and glycoprotein concentrations, and ameliorated the depleted antioxidant enzyme activities (SOD, CT, GR, GPx, GST) of ulcerated rats to values relatively close to those of the omeprazole group used as the reference antiulcer drug. This efficacy exhibited by the extract at $200 \mathrm{mg} / \mathrm{kg}$ b.w. may be attributed to the interaction effects of the chemical constituents present in the extract which could be synergistic, additive, or antagonistic.

Chromosomal aberration assays are used to detect agents (i.e., clastogens) that cause chromosome damage, which may be chromatid, chromosome breaks, and complex chromosome changes in the form of exchanges, rings, and dicentrics. The induction of chromosomal aberrations in cells may play an essential role in the development of certain tumor and it is believed to be a relevant biomarker for cancer risk in humans. ${ }^{57}$ An increase in frequencies of mitotic chromosome breakage may indicate that a chemical has the potential to induce numerical aberrations. ${ }^{57}$ In this study, there was no increase in the frequencies of chromosomal aberration in the kidney and liver of rats following the administration of 100 and $200 \mathrm{mg} / \mathrm{kg}$ b.w. of the extract, this means that the extract may be considered safe at these doses. On the contrary, the increase observed in the frequencies of chromosomal aberration in the liver and kidney of rats that received $400 \mathrm{mg} / \mathrm{kg}$ b.w. of the extract could indicate that at a much higher dose of $400 \mathrm{mg} / \mathrm{kg}$ b.w., the extract may not be safe for consumption. This observation may be in connection with the high amount of alkaloids present in the extract. Dalvi ${ }^{58}$ and El-Gamal ${ }^{59}$ have reported the DNA damage and cytotoxicity associated with alkaloids found in different extracts of A. mexicana. Also, Manjamalai et $\mathrm{al}^{60}$ in their study reported the deoxyribonucleic acid damage of blood cells and bone marrow in mice administered extract of $A$. mexicana. In addition, sanguinarine, an alkaloid isolated from A. mexicana oil, has been reported to cause in vivo damage to the DNA in mice as the rate of chromosomal aberration; micronuclei formation and development of comets were seen to be increased. ${ }^{61}$

\section{Conclusion}

The study concluded that $A$. mexicana exhibits antiulcer activity in rats and is considered safe at a low dose. Therefore, it may be employed as an alternative source for development of new and safer antiulcer drugs. Further work is ongoing to isolate the bioactive principle(s) responsible for the antiulcer activity of the plant.

\section{Funding}

This research did not receive any funding.

\section{Conflict of Interest}

The authors declare that they have no conflicts of interest.

\section{References}

1 Garg S, Pal K, Sharma A, Garg K. Ethnopharmacological evaluation of antiulcer activity of Caralluma attenuta. IJPLS 2014;5(06): 3585-3589

2 Kumar V, Abbas A, Fausto N, Aster J. Robbins and Cotran Pathologic Basis of Disease. The gastrointestinal tract, 8th ed. Amsterdam: Elsevier Publisher; 2009;14:798-847

3 Lozano R, Naghavi M, Foreman K, et al. Global and regional mortality from 235 causes of death for 20 age groups in 1990 and 2010: a systematic analysis for the Global Burden of Disease Study 2010. Lancet 2012;380(9859):2095-2128

4 Søreide K, Thorsen K, Harrison EM, et al. Perforated peptic ulcer. Lancet 2015;386(10000):1288-1298

5 Hooi JKY, Lai WY, Ng WK, et al. Global prevalence of Helicobacter pylori infection: systematic review and meta-analysis. Gastroenterology 2017;153(02):420-429

6 Das AK, Bigoniya P, Verma NK, Rana AC. Gastroprotective effect of Achyranthes aspera Linn. leaf on rats. Asian Pac J Trop Med 2012;5 (03):197-201

7 Maes ML, Fixen DR, Linnebur SA. Adverse effects of proton-pump inhibitor use in older adults: a review of the evidence. Ther Adv Drug Saf 2017;8(09):273-297

8 Mössner J. The indications, applications, and risks of proton pump inhibitors. Dtsch Arztebl Int 2016;113(27-28):477-483

9 Magaji RA, Okasha MAM, Abubakar MS, Fatihu MY. Anti-ulcerogenic and andti-secretory activity of the n-butanol portion of Syzygium aromaticum in rat. Niger J Pharm Sci 2007;6(02): 119-126

10 Sonibare MA, Moody JO, Adesanya EO. Use of medicinal plants for the treatment of measles in Nigeria. J Ethnopharmacol 2009;122 (02):268-272

11 Kayode J, Kayode GM. Ethnomedicinal survey of botanicals used in treating sexually transmitted diseases in Ekiti State, Nigeria. Ethnobotanical Leaflets 2008;12:44-55

12 Aiyeloja AA, Bello OA. Ethnobotanical potentials of some herbs in Nigeria. A case study of Enugu State. Educ Res Rev 2006;1(01): $16-22$

13 Bhat RB, Etejere EO, Oladipo VT. Ethnobotanical studies from central Nigeria. Econ Bot 1990;44(03):382-390

14 Das PK, Seth R, Panda P, Pani SM. Hepatoprotective activity of plant Argemone mexicana (linn).against carbon tetrachloride $\left(\mathrm{CCl}_{4}\right)$ induced hepatoxicity in rats. Int J Pharm Res Dev 2009;8 (02): $1-20$

15 Organization for Economic Co-operation and Development Acute oral toxicity-Acute oral toxic class method, guideline 423, adopted December 17, 2001:1-14

16 Harbone JB. Phytochemical Methods: A guide to modern techniques of plant analysis. 2nd ed. London: Chapman \& Hall; 1984; 49:4-14

17 Sofowora A. Medicinal plants and traditional medicines in Africa. 2nd ed. Ibadan: Spectrum; 1993:134-156

18 Trease GE, Evans WC. A textbook of pharmacognosy. 13th ed. Philadelphia: Bailleire-Tindall; 1989:824-832

19 Gregory M, Vithalrao KP, Franklin G, Kalaichelavan V. Anti-ulcer (Ulcer-preventive) activity of Ficus arnottiana Miq. (Moraceae) leaf methanolic extract. Am J Pharmacol Toxicol 2009;4(03):89-93 
20 Parmar NS, Hennings G. The gastric antisecretory activity of 3methoxy-5,7,3',4' tetrahydroflavin (ME) - a specific histidine decarboxylase inhibitor in rats. Agents Actions 1984;15(3-4):143-145

21 Hirohashi M, Takasuna K, Kasi Y, Usui C, Tamura K, Kojima H. General pharmacological profile of the new anti-ulcer drug 3-[[[2(3,4-dimethoxyphenyl)ethyl]carbamoyl]methyl]-amino-N -methylbenzamide. Arzneimittelforschung 1993;43(05):569-577

22 Nair BR. Investigations on the Neuron of South Indian Scorpion Hetrometrus Scaber [PhD dissertation]. Trivendrum (Kerala): University of Kerala; 1976

23 Lowry OH, Rosebrough NJ, Farr AL, Randall RJ. Protein measurement with the Folin phenol reagent. J Biol Chem 1951;193(01): 265-275

24 Reyes-Chilpa R, Baggio CH, Alavez-Solano D, et al. Inhibition of gastric $\mathrm{H}^{+}, \mathrm{K}^{+}$-ATPase activity by flavonoids, coumarins and xanthones isolated from Mexican medicinal plants. J Ethnopharmacol 2006;105(1-2):167-172

25 Corne SJ, Morrissey SM, Woods RJ. Proceedings: a method for the quantitative estimation of gastric barrier mucus. J Physiol 1974; 242(02):116P-117P

26 Ellman GL. Tissue sulfhydryl groups. Arch Biochem Biophys 1959; 82(01):70-77

27 Buege JA, Aust SD. Microsomal lipid peroxidation. Methods Enzymol 1978;52:302-310

28 Mistra HP, Fridovich I. The role of superoxide anion in the autooxidation of epinephrine and simple assay for superoxide dismutase. J Biochem 1972;247(10):3170-3175

29 Beers RFJr, Sizer IW. A spectrophotometric method for measuring the breakdown of hydrogen peroxide by catalase. J Biol Chem 1952;195(01):133-140

30 Goldberg DM, Spooner R, Bergmeyen HV. Assay of glutathione reductase. In: Bergmeyen HV, ed. Methods of Enzymatic Analysis. 3rd ed. Florida: Verlog Chemie; 1983:258-265

31 Paglia DE, Valentine WN. Studies on the quantitative and qualitative characterization of erythrocyte glutathione peroxidase. J Lab Clin Med 1967;70(01):158-169

32 Habig WH, Pabst MJ, Jakoby WB. Glutathione S-transferases. The first enzymatic step in mercapturic acid formation. J Biol Chem 1974;249(22):7130-7139

33 Krause WJ. The art of examining and interprinting histologic preparations. A laboratory manual and study guide. USA: Universal Publishers; 2004;89:9-10

34 Perumal P, Sekar V, Rajesh V, Gandhimethi S, Sampathkumar R, Shuja-Nazimudin KH. In vitro antioxidant activity of $A$. mexicana roots. Int J Pharm Tech Res 2010;2(02):1477-1482

35 Wan YJ. Effect of anisodamine on gastric ulcer induced by restraint water-immersion in rats. Exp Clin Gastroenterol 1993;3:154-158

36 Cook NC, Samman S. Flavonoids-chemistry, metabolism, cardioprotective effects and dietary sources. J Nutr Biochem 1996;7(02):66-74

37 Galati EM, Monforte MT, Tripodo MM, d'Aquino A, Mondello MR. Antiulcer activity of Opuntia ficus indica (L.) Mill. (Cactaceae): ultrastructural study. J Ethnopharmacol 2001;76(01):1-9

38 Fan TY, Feng QQ Jia CR, Fan Q Li CA, Bai XL. Protective effect of Weikang decoction and partial ingredients on model rat with gastric mucosa ulcer. World J Gastroenterol 2005;11(08):1204-1209

39 Balogun ME, Oji JO, Besong EE, Ajah AA, Michael EM. Anti-ulcer activity of aqueous leaf extract of Nauclea latifolia (Rubiaceae) on indomethacin-induced gastric ulcer in rats. Afr J Biotechnol 2013; 12(32):5080-5086

40 Saheed S, Sulyman AO, Garuba T, Sunmonu TO, Abdulrahaman AA. Combined administration of Spondias mombin and Ficus exasperata leaf extracts stall indomethacin-mediated gastric mucosal onslaught in rats. Afr J Tradit Complement Altern Med 2015;12(01):45-51

41 Lichtenberger LM. The hydrophobic barrier properties of gastrointestinal mucus. Annu Rev Physiol 1995;57(01):565-583
42 Wada K, Kamisaki Y, Nakamoto K, Kishimoto Y, Ashida K, Itoh T. Effect of plaunotol on gastric injury induced by ischaemia-reperfusion in rats. J Pharm Pharmacol 1997;49(09):903-907

43 Cheung DY, Kim JI, Park SH, Kim JK. Proanthocyanidin from grape seed extracts protects indomethacin-induced small intestinal mucosal injury. Gastroenterol Res Pract 2014;2014(01):618068

44 Yin H, Pan X, Song Z, Wang S, Yang L, Sun G. Protective effect of wheat peptides against indomethacin-induced oxidative stress in IEC-6 cells. Nutrients 2014;6(02):564-574

45 Selvamathy SMKN, Geetha A, Saranya P. Gastroprotective effect of Swertia chirayita- a study with ulcer induced rats. Pharmacologyonline 2010;1:332-355

46 Mahmoud AH, Farrag EM, Fayed DB. Antiulcer activity Citharexylum quadrangular JACQ leaves (ethanolic extract) on experimentally induced gastric ulceration rats. World J Pharm Pharm Sci 2016;5(02):145-159

47 Beck PL, Xavier R, Lu N, et al. Mechanisms of NSAID-induced gastrointestinal injury defined using mutant mice. Gastroenterology 2000;119(03):699-705

48 Adhikary B, Yadav SK, Roy K, Bandyopadhyay SK, Chattopadhyay S. Black tea and theaflavins assist healing of indomethacin-induced gastric ulceration in mice by antioxidative action. Evid Based Complement Alternat Med 2011;2011:546560

49 Muhammed AVK, Thamotharan G, Sengottuvelu S, Haja-Sherief S, Sivakumar T. Evaluation of antiulcer activity of Ficus pumila L. leaf extract in albino rats. Glob J Res Med Plants Indig Med 2012;1(08): 340-351

50 Berg JM, Tymoczko JL, Stryer L, Gatto GJ. Biochemistry. 7th ed. Basingstoke: W.H. Freeman; 2012;32:234-247

51 Lewis DA, Hanson PJ. Anti-ulcer drugs of plant origin. Prog Med Chem 1991;28:201-231

52 Pandian RS, Anuradha CV, Viswanathan P. Gastroprotective effect of fenugreek seeds (Trigonella foenum graecum) on experimental gastric ulcer in rats. J Ethnopharmacol 2002;81(03):393-397

53 Salim AS. The relationship between Helicobacter pylori and oxygen-derived free radicals in the mechanism of duodenal ulceration. Intern Med 1993;32(05):359-364

54 Dash GK, Murthy PN. Evaluation of Argemone mexicana Linn. Leaves for wound healing activity. J Nat Prod Plant Resour 2011;1(01):46-56

55 Maity P, Bindu S, Dey S, et al. Indomethacin, a non-steroidal anti-inflammatory drug, develops gastropathy by inducing reactive oxygen species-mediated mitochondrial pathology and associated apoptosis in gastric mucosa: a novel role of mitochondrial aconitase oxidation. J Biol Chem 2009;284(05): 3058-3068

56 Halici M, Odabasoglu F, Suleyman H, Cakir A, Aslan A, Bayir Y. Effects of water extract of Usnea longissima on antioxidant enzyme activity and mucosal damage caused by indomethacin in rats. Phytomedicine 2005;12(09):656-662

57 Bonassi S, Hagmar L, Strömberg U, et al;European Study Group on Cytogenetic Biomarkers and Health. Chromosomal aberrations in lymphocytes predict human cancer independently of exposure to carcinogens. Cancer Res 2000;60(06):1619-1625

58 Dalvi RR. Sanguinarine: its potential as a liver toxic alkaloid present in the seeds of Argemone mexicana. Experientia 1985; 41(01):77-78

59 El-Gamal AA. Phytochemistry, Pharmacology and Toxicology of Argemone mexicana L. [PhD Thesis]. Khartoum: University of Khartoum; 1995

60 Manjamalai A, Sardar-Sathyajith-Singh R, Guruvayoorappan C, Berlin-Grace VM. Analysis of phytochemical constituents and anti-microbial activity of some medicinal plants in Tamil Naidu, India. Global J Biotech Biochem 2010;5(02):120-128

61 Anartha S, Chaudhari S. Neuropharmacological study of Argemon mexicana Linn. J Appl Pharm Sci 2011;1(04):121-126 